\title{
Stock assessment methods used for cephalopod fisheries
}

Graham J. Pierce ${ }^{a^{*}}$, Angel Guerra ${ }^{b}$

${ }^{a}$ Department of Zoology, University of Aberdeen, Tillydrone Avenue, Aberdeen AB9

$2 \mathrm{TN}, \mathrm{UK}$

${ }^{\mathrm{b}}$ Instituto de Investigaciones Marinas, Eduardo Cabello 6, 36208 Vigo, Spain

* Corresponding author.

\section{Abstract}

Cephalopods are of increasing importance as a fishery resource and many species are taken in directed and bycatch fisheries around the world. Owing to the short life-cycles and variable growth rates of most cephalopods, stocks may be highly volatile, both highly susceptible to recruitment overfishing and, conversely, capable of rapid recovery. Many species have protracted spawning seasons so that multiple microcohorts may be present in the population at any one time.

Many assessment methods have been applied to cephalopod stocks, including stock recruitment relationships (e.g. the Japanese Todarodes pacificus stock), recruitment indices (e.g. Saharan Bank cephalopod stocks), swept-area biomass estimates (e.g. Northwest Atlantic stocks of the squids Loligo pealei and Illex illecebrosus), production models (e.g, Saharan Bank cephalopod stocks), cohort analysis (e.g. Illex argentinus in the Falkland islands), yield-per-recruit models (e.g. Northwest Atlantic squid stocks), length-based cohort analysis (e.g. Dosidicus gigas in the Gulf of California), and depletion estimates of stock size (e.g. Illex argentinus in the Falkland islands).

Despite the widespread application of assessment methods, few stocks are rigorously managed, and the best example of a regulated fishery is the Falkland islands squid fishery. In contrast, although a number of assessment methods are used in the Japanese Todarodes fishery, management activities arc designed to ensure harmonious operation of the industry rather than maintain stock size. Fisheries for Loligo forbesi and Loligo vulgaris in the Northeast Atlantic arc mainly based on by-catches, although there is some directed fishing, particularly artisanal jig fishing in coastal waters. There is currently no assessment and minimal management for these species, and available 
management options are constrained by the nature of the fishery and the generally poor quality of available data.

Keywords: Cephalopods, general; Stock assessment

\section{Introduction}

Although cephalopods make up only a small proportion of world fish landings (approximately 2\% of finfish landings; Worms, 1983; Rodhouse, 1989), there have been substantial increases during the last three decades (Worms, 1983; Rathjen and Voss, 1987; Boyle, 1990; Rosenberg et al., 1990; Guerra, 1992), and total world landings of cephalopods reached 2.56 million $\mathrm{t}$ in 1991 (Food and Agriculture Organization (FAO), 1991). The increased relative abundance of cephalopods reflects, at least in part, reduction in competition and predation owing to diminished stocks of some finfish and marine mammals (Voss, 1973; Arnold, 1979; Bas, 1979; Caddy, 1981, 1983; Bravo de Laguna, 1989).

There may be considerable scope for further increases in cephalopod landings. Potential annual landings of neritic cephalopods, from continental shelves and slopes, of 6-12 million tonnes have been suggested (Voss, 1973; Guerra and Pérez-Gándaras, 1983), while the potential yield from oceanic cephalopods estimated in terms of the food resources of various predators appears to be some 50 times greater (Clarke, 1987).

Some of the more important cephalopod fisheries from around the world are listed in Table 1. Although many more species are fished commercially, approximately 45 species are of major importance (Guerra, 1992). The main species of commercial importance in the Northeast Atlantic are the octopuses Octopus vulgaris and Eledone cirrhosa, the cuttlefish Sepia officinalis and the squids Loligo forbesi, Loligo vulgaris (Loliginidae), Todarodes sagittatus, Todaropsis eblanae and Illex coindetii (Ommastrephidae) (Guerra and Pérez-Gándaras, 1983; Roper et al., 1984; Anonymous, 1988; González et al., 1992). In this area, most cephalopods are landed as a by-catch of trawling for demersal fish, e.g. Loligo forbesi in the UK (Thomas, 1969; Thomas and Davidson, 1972; Howard, 1979; Howard et al., 1987; Pierce et al., 1994a). 
The biology of cephalopods poses particular problems for fishery assessment and management, both in respect of the poor state of knowledge of many species and as a consequence of the short life cycle (Arnold, 1979; Caddy, 1983; Voss, 1983; Bravo de Laguna, 1989; Rosenberg et al., 1990). The short life-cycle offers little opportunity to adjust fishing strategy during the lifetime of any one cohort (Bravo de Laguna, 1989) and makes cephalopod stocks particularly vulnerable to overfishing (Rosenberg et al., 1990). Some cephalopod fisheries have already declined. Murata (1989) attributes the decline in stocks of Japanese common squid (Todarodes pacificus) in the 1970s to excessive fishing intensity at a time when the stock had fallen naturally to a low level. The Saharan Bank squid fishery started to decline in 1982 but it is not clear whether this was due to natural fluctuation or overfishing (Bravo de Laguna, 1989).

Cephalopod fisheries and fishery biology have been reviewed a number of times in the last two decades (Zuev and Nesis, 1971; Voss, 1973, 1983; Arnold, 1979; Okutani, 1980; Caddy, 1983; Worms, 1983; Guerra and Pérez-Gándaras, 1983; Pauly, 1985; Rathjen and Voss, 1987; Boyle, 1990; Rathjen, 1991). During this period, as cephalopod fisheries have expanded, new assessment and management methods have been developed and applied. Nevertheless, Rosenberg et al. (1990) observed that assessment and management methods suitable for fisheries on annual squid species remain poorly developed.

In the present paper we review aspects of cephalopod population biology which pose particular problems for assessment and management, and examine a range of assessment methodologies applied or applicable to cephalopods. Management options are discussed, with particular attention given to prospects for managing squid stocks in European Community waters.

\section{Cephalopod population biology}

The critical population parameters for assessing stock characteristics include biomass, recruitment, growth rates, age, natural and fishing mortality, fecundity, and the interrelationships between and environmental correlates of these parameters. 
Cephalopods differ fundamentally from most temperate finfish by being short lived. Many cephalopod species have a monocyclic sexual system and live for only 1 year (Boyle, 1990). If breeding is synchronous, the generations may not overlap. Thus no spawning stock of animals is carried over from one year to the next. Annual recruitment contributes almost the entire overall stock biomass (Caddy, 1983; Pauly, 1985; Beddington et al., 1990; Rosenberg et al., 1990) and is therefore a particularly significant parameter for stock assessment (Pauly, 1985).

There may be high variability in abundance from year to year. Based on stock size estimates for Illex argentinus in the southwest Atlantic by Csirke (1987), Beddington et al. (1990) suggested that recruitment varied between years by a factor of ten.

Growth, as might be expected for short-lived species, is very rapid and is also thought to be very labile and sensitive to environmental conditions (Caddy, 1983; Coelho, 1985; Pauly, 1985; Forsythe and Van Heukelem, 1987). The form of the growth curve appears to be highly variable, although Pauly (1985) argues that all observed growth curves fit the von Bertalanffy model with an additional term allowing seasonal variation.

The short life-cycle invites comparison with short-lived tropical fish and crustacean species for which length-based cohort analysis was developed. However, many cephalopod species have protracted spawning seasons and, consequently, multiple 'microcohorts' are present at any one time (e.g. Lange and Sissenwine, 1983). These may be difficult to resolve statistically, particularly if, as is likely, each microcohort has a different growth rate.

Cephalopod statoliths show growth increments and their use in age estimation is becoming established. For many species it has been shown that growth rings are deposited daily. For a recent compilation of studies, see Jereb et al. (1991). This opens up the possibility of using age-based assessment even if age can not be reliably estimated from length.

Most cephalopods, but particularly squid, have one or more migratory phase in their life-cycle (Caddy, 1983). Unpredictable movement patterns may be a component of 
variability in recruitment to the fishery since, depending on their distribution, some of the incoming recruits to the population may be inaccessible to the fishery.

Cannibalism may be a large component of natural mortality in cephalopods (Mohn, 1981; Caddy, 1983), while Saville (1987) argues that the relatively small difference in form between squid paralarvae and adults, and the short period of between hatching and adoption of adult form, is likely to mean that mortality at this stage is much lower than in fish.

In respect of their short-life cycles, cephalopods may be thought of as opportunistic rstrategists, whereas most commercial bottomfish are K-strategists (MacArthur and Wilson, 1967). However, other characteristics, e.g. relatively low fecundity, and a high degree of protection afforded to the eggs, compared with fish (Caddy, 1983; Saville, 1987; Anonymous, 1988), suggest that such a simplistic view is misleading.

While some authors have highlighted the susceptibility of cephalopod stocks to overfishing (Rosenberg et al., 1990), Caddy (1983) suggests that the cephalopod 'lifestrategy' may be superior to that of long-lived fish under conditions of environmental stress, e.g. as caused by heavy fishing.

\section{Fishing methods for cephalopods}

Fishing methods used to capture cephalopods have been reviewed by Arnold (1979), Voss (1973), Rathjen and Voss (1987) and Rathjen (1991). Jigging is the most important method of squid fishing. It has been used by Japanese fishermen since the 17 th century, accounting for $95 \%$ of Japanese squid catches and some $40 \%$ of world cephalopod catches (Arnold, 1979; Rathjen and Voss, 1987; Rathjen, 1991). Jigs are small grapnels with one or two rings of barbless hooks. These are attached to lines, traditionally hand held but now usually deployed using automatic machines, and jerked up and down (Arnold, 1979; Hamabe et al., 1982; Guerra, 1985). Many pelagic cephalopods are positively phototropic and light attraction is used in conjunction with other fishing methods, including jigging. Jigging (for Loligo forbesi) is carried out during daylight in the Azores archipelago (Martins, 1982). 
Trawling is the second most important fishing technique for cephalopods, accounting for $25 \%$ of world catches (Rathjen, 1991). Various forms of trawling are used, including single and pair, demersal and midwater trawls. The directed offshore fisheries for Illex illecebrosus in the Northwest Atlantic make use of bottom otter trawls and midwater trawls. In the UK, squid (Loligo forbesi) are landed principally as a by-catch of demersal trawling and seine net fishing (Arnold, 1979; Pierce et al., 1994a).

Of other methods, gill netting was recognised as the most important by Rathjen (1991), recorded as taking $10 \%$ of world cephalopod catches, notably in the North Pacific (Arnold, 1979; Rathjen and Voss, 1987). The importance of gill netting is likely to decline under recent restrictions. Seine netting is a productive method for catching cephalopods in various parts of the world, e.g. the Philippines (Hernando and Flores, 1981). A wide range of other methods has been used including roundhaul nets and lift nets in the fishery for Loligo opalescens off California. Small amounts of squid are also caught by a wide range of gear-types in Spanish and UK waters, including long lines, gill nets, drift nets, tangle nets and dredges (Guerra and Pérez-Gándaras, 1983; Guerra et al., 1994; Pierce et al., 1994a). Octopus are traditionally caught using pots, traps, and spears, as well as by trawling (Guerra and Pérez-Gándaras, 1983).

\section{Sampling cephalopod populations}

Two basic kinds of data are needed for assessments: commercial fishing data and biological data, although precise data requirements vary between methods. All data are likely to be imperfect, e.g. because fishing gear is size-selective.

\subsection{Commercial fishing data}

Where managed cephalopod fisheries exist, routine collection of fishery data is normally in place. This may be based on information obtained from fishermen, markets, and, particularly when real time assessment is needed, as in the Falklands, using observers placed on commercial boats. Inevitably, less information in available for unmanaged stocks, e.g. Loligo spp. in the Northeast Atlantic. 
An understanding of the dynamics of a system often requires experimental perturbation or, at least, examination of the consequences of allowing the stock size or fishing intensity to vary across a wide range of values. However, in a commercial fishery such fluctuations may have undesirable short-term economic and social costs (Hilborn and Walters, 1992).

\subsection{Biological data}

Available sampling methods for population parameters include sampling from commercial boats or markets, research trawling and acoustic surveys for adults, and plankton surveys for juveniles. Again, there is obviously less information available on unmanaged stocks. Thus, in the UK, little research vessel activity is directed primarily at cephalopods, although length-frequency data for squid caught in research trawls are recorded by Scottish Office research vessels.

All fishing gear is to some extent selective, e.g. small animals pass large-mesh nets and larger animals may be able to swim fast enough to avoid capture. However, selectivity curves for cephalopods caught in trawls tend to be rather irregular, perhaps because arms and tentacles impede the escape of even small animals, while the plasticity of the body may assist large individuals to escape (Caddy, 1983). Clarke (1983) showed that squid caught in commercial nets were bigger than those in research trawls but markedly smaller than those eaten by sperm whales: each sampled only a proportion of the population. Jigs can be species specific although it is unclear whether particular size classes are caught (Caddy, 1983).

Another consideration is temporal and spatial pattern in population structure. The distribution of commercial fishing is unlikely to match the distribution of the stock, particularly for a multispecies fishery, either in terms of geographical coverage or the depth range fished, and some population components will inevitably be underrepresented.

Sampling for paralarvae and juveniles presents particular problems; there is a need for improved sampling gear and better knowledge of the biology of early life stages before routine quantitative sampling is possible (Anonymous, 1993). 


\section{Assessment methods}

Two general categories of assessment may be distinguished: in-season assessments and post-season assessments. The methods may be the same but the applications are different. The former makes use of (incomplete) data as they are collected, and may be used to adjust levels of fishing activity during a season, while the latter, based on the complete dataset for a season, can be used to establish relationships between variables (e.g. between spawning stock size and recruitment) and to establish management goals for the following season (Basson et al., 1994).

A consequence of the short lifespan and sensitivity to environmental conditions is that management of cephalopod stocks requires assessment to operate on a shorter timescale than is necessary for many finfish. To minimise the risk of overexploitation, real time (in-season) assessment and management may be necessary (Caddy, 1981, 1983; Rosenberg et al., 1990). Often, assessment must start from scratch every year as one generation is replaced by the next, and the only relationship between fisheries in successive years operates through the stock-recruitment relationship, if any (Beddington et al., 1990; Rosenberg et al., 1990).

Most standard assessment methodologies were developed for application to temperate finfish stocks. Nevertheless, many have been applied to cephalopods, including stockrecruitment models based on the methods of Ricker (1954) and Beverton and Holt (1957), depletion estimates (De Lury, 1947), cohort analysis (Fry, 1949; Jones, 1961; Gulland, 1965; Murphy, 1965; Tomlinson, 1970; Pope, 1972), yield-per-recruit (Ricker, 1958) and production models (Schaefer, 1954; Pella and Tomlinson, 1969; Fox, 1970).

Assessment provides not only the data necessary for management, but also valuable ecological information, helping to quantify the likely impacts of cephalopod stocks on other fished stocks. We now review the range of approaches available, including recent developments, and discuss examples of their application to cephalopod fisheries.

\section{Stock identification and distribution}


A necessary precursor to any management is to define the identity and distribution of stocks on which fishing takes place. Stocks may be empirically defined on the basis of identifiable fishing grounds, but for mobile species such as squid this may not be useful. Information on squid distribution is based largely on fishery data and little is known about distribution in areas where there is no fishing (Anonymous, 1988).

Since most cephalopods undergo migrations, distribution tends to change over the course of the life-cycle. It has been suggested that, in some fisheries, the squid exploited are part of a larger stock which has moved so far from the spawning grounds that they would not be able to return in time to spawn and, as such, fisheries are taking animals already lost from the spawning population (Anonymous, 1988). This is, however, a dangerous assumption to make.

Evidence on stock identity may also be gained from ecological data. Thus, on the basis of spawning seasons, growth types and migratory patterns, three subpopulations of Todarodes pacificus are believed to exist in the Sea of Japan (Murata, 1989). Tagging studies have proven very useful in elucidating migration patterns in different squid species (e.g. Hamabe and Shimizu, 1966; Hurley and Dawe, 1980).

Methodology developed in studies of geographic variation, phylogeny and population genetics has been applied to stock identification. Methods available include multivariate analysis of morphometric data, allozyme electrophoresis and DNA sequencing. The former methods have already been applied to some squid stocks (e.g. Kristensen, 1982; Carvalho and Loney, 1989; Carvalho and Pitcher, 1989; Carvalho et al., 1992; Brierley et al., 1994; Pierce et al., 1994c).

Almost all stock assessment procedures assume that the population being sampled or fished is a unit stock, although in many models it is possible to incorporate emigration and/or immigration as separate parameters.

\section{Stock-recruitment models}

Stock-recruitment models are normally used as part of an age-structured assessment, to predict the size of the incoming year class. However, for semelparous or monocyclic 
species they may be used on their own (Hilborn and Waiters, 1992). For annual cephalopod species, in which adults spawn only once and the following year's stock will consist entirely or almost entirely of new recruits, a stock-recruitment relationship, however weak, provides the only means of predicting stock size from the previous year's data (Beddington et al., 1990).

The basic underlying assumption of this approach is that a fixed relationship exists between stock size in one year and recruitment in the following year. Thus measures of both stock size and recruitment are needed.

A range of types of relationship may exist between stock size and recruitment. Mortality of juveniles may be density-independent (in which case recruitment will be proportional to spawning stock size), density-dependent (e.g. the Beverton-Holt model), or depensatory (in which the number of recruits per spawner increases with stock size). Analysis of stock-recruitment data is usually performed by fitting standard curves to data on stock size and recruitment.

The best known stock-recruitment models are those of Ricker (1954) and Beverton and Holt (1957). The latter model assumes that juvenile mortality is density-dependent and is as follows:

$$
R=\frac{a S}{b+S}
$$

where $\mathrm{R}$ is recruitment, Sis spawning stock, $\mathrm{a}$ is the maximum number of recruits produced and $\mathrm{b}$ is the spawning stock needed to produce $\mathrm{a} / 2$ recruits. This model produces asymptotic curves with initial slopes of $a / b$. One of several alternative formulations, with parameters $\alpha$ and $\beta$ is

$$
R=\frac{1}{\alpha+\beta / S}
$$

If $\mathrm{S}$ is replaced by $\mathrm{E}$ (the number of eggs produced by the parental stock), the parameters may be interpreted as representing the density independent $(\alpha)$ and density dependent $(\beta)$ components of total mortality. This version produces hyperbolic curves. The Ricker model is

$\mathrm{R}=\mathrm{Se}^{\mathrm{a}(1-\mathrm{S} / \mathrm{b})}$ 
where $\mathrm{e}^{\mathrm{a}}$ is the initial slope of the curve, $\mathrm{b}$ is the value of $\mathrm{S}$ at which $\mathrm{R}=\mathrm{S}$. This model assumes that juvenile mortality is stock-dependent (i.e. proportional to initial cohort size rather than proportional to current cohort size) and generates a range of curve shapes in which the absolute number of recruits is maximised at an intermediate stock size.

Assessment for the Todarodes pacificus fishery in the Sea of Japan is based on a synthesis of several sources of data, including plankton surveys for juveniles and experimental jig fishing surveys for pre-recruits (Murata, 1989). There is an empirical linear relationship between stock size (estimated as catch per fishing vessel, U) and an index of larval density $\left(\mathrm{L}_{\mathrm{p}}\right)$ calculated from results of plankton surveys. Total catch was a good predictor of larval density $(\mathrm{R}=0.8996$, data from 1973-1984) (Okutani and Watanabe, 1983; Murata, 1989).

Both Beverton and Holt and Ricker models can be solved by regression analysis, but the distribution of errors is not log-normal so parameter estimates are biased and must be corrected (Hilborn and Waiters, 1992). Any method which involves linearising of equations by transformation carries the risk of producing biased parameter estimates and the likely statistical distribution of errors should always be considered.

Another drawback of using these average curves is that they do not express the underlying stochasticity in the stock-recruitment relationship, which may be both weak and variable (Rosenberg et al., 1990; Hilborn and Waiters, 1992). In most demersal fish stocks, each cohort lives and spawns over several years and assessment may be robust to fluctuations in recruitment. For squid, the range of possible recruitment may be so weak that knowing the average is of little value for management purposes. The likely minimum can however be used to develop a conservative management policy, preventing the stock falling below some target threshold (G. Tingley, personal communication, 1993).

\section{Surveys and recruitment indices}

In many temperate fin fish fisheries, surveys of pre-recruits are used to estimate the strength of the incoming year-class (Rosenberg et al., 1990). Surveys may also be used to estimate adult stock size directly. 
Using a stratified random survey, total stock size $\left(\mathrm{B}_{\mathrm{T}}\right)$ is given by

$$
B_{T}=\sum\left(\frac{A_{i}}{b_{i}} Y_{i}\right)
$$

where $A_{i}$ is area of stratum $i, b_{i}$ is the area swept in stratum $i, Y_{i}$ is catch for stratum $i$. If $\mathrm{S}_{\mathrm{i}}$ is the variance for $\mathrm{n}_{\mathrm{i}}$ tows in stratum $\mathrm{i}$, the variance of $\mathrm{B}_{\mathrm{T}}$ is given by

$$
S_{B}^{2}=\sum\left[\frac{A_{i}^{2} n_{i} S_{i}^{2}}{b_{i}^{2}}\right]
$$

Caddy (1983) proposes some possible recruitment indices: (a) if effort and catchability are reasonably constant, annual catches may provide a direct index of recruitment; (b) the catch rate at the start of the season may be an index of yield for the rest of the season.

Attempts have been made to develop acoustic survey methods for squid, (Arnaya et al., 1988, 1989). This is a promising approach although calibrating target strength with cephalopod density remains a problem and the echo signatures of species need to be identified (Anonymous, 1993).

Indirect measures of abundance could be obtained from studies of the importance of cephalopods in predator diets (Clarke, 1987). However, the utility of such information is questionable since diet choice probably depends on the relative abundances of a range of prey species.

There are numerous examples of the use of surveys and recruitment indices for cephalopod stocks. In the Saharan Bank octopus fishery, recruitment indices have been derived from CPUE for the smallest size class of octopus, although this was as a monitoring procedure rather than a management tool (Bravo de Laguna, 1989). In the Northwest Atlantic, bottom trawl surveys are used to provide a prerecruit index for Loligo pealei and Illex illecebrosus (Lange and Sissenwine, 1983). In the Todarodes pacificus fishery in the Sea of Japan, the index of larval density (see previous section) calculated from results of plankton surveys is of potential use as an index of subsequent stock size: a positive correlation $(\mathrm{R}=0.7575)$ between larval density and total catches 
in the next year exists for data from 1973 to 1984 (Okutani and Watanabe, 1983; Murata, 1989). Swept-area estimates of adult stock size have been used for various stocks, including the Northwest Atlantic stocks of Loligo pealei and Illex illecebrosus (Lange and Sissenwine, 1983; Rowell et al., 1985), South African stocks of Loligo vulgaris reynaudi (Augustyn et al., 1992), arrow squid (Nototodarus sloani) in New Zealand waters, and Illex argentinus stocks off the coast of Argentina (Sato and Hatanaka, 1983).

As in the case of formal stock-recruitment models, the cost of being wrong in assessment of recruitment is much greater for annual species (Caddy, 1983). The problem of assessing recruitment is complicated for some cephalopods in that recruitment occurs over a prolonged period and there may be several population components recruiting at different times of year (Caddy, 1983). Even if there is a single period of recruitment, climatic fluctuations may lead to differences in the timing of recruitment to the fishery, often by several weeks in the case of Illex argentinus and Loligo gahi in the southwest Atlantic. Thus year to year comparisons of early season catch rates should be made with caution (G. Tingley, personal communication, 1993).

\section{Biomass dynamic models}

Defining surplus production as the difference between production and natural mortality, biomass dynamic or production models describe the relationship between surplus production and stock biomass or an index of stock biomass. Application of these models requires time series data on catches and abundance, the latter normally expressed as an index, e.g. catch per unit effort (CPUE). The first widely used model was the Schaefer (1954) model

$$
\frac{d B}{d t}=r B\left(1-\frac{B}{k}\right)-C
$$

where $\mathrm{r}$ is the intrinsic rate of population growth, $\mathrm{k}$ is equilibrium stock size (unfished), $\mathrm{B}$ is biomass and $\mathrm{C}$ is catch rate. Assuming that catch is proportional to stock size (B) and fishing effort $(\mathrm{E})$ $\mathrm{C}=\mathrm{qEB}$ 
where $\mathrm{q}$ is a parameter describing the effectiveness of fishing effort, or catch coefficient. Then, catch per unit effort (CPUE or U) can be used as an index of stock abundance

$\mathrm{U}=\mathrm{C} / \mathrm{E}=\mathrm{qB}$

Pella and Tomlinson's (1969) generalisation of the Schaefer model includes the additional parameter $\mathrm{m}$, allowing variation in the shape of the relationship

$$
\frac{d B}{d t}=r B-\frac{r}{K} B^{m}-C
$$

There are three general methods for parameter estimation (Hilborn and Waiters, 1992). Firstly, optimum effort and CPUE may be estimated by assuming that the stock is at equilibrium, in which case $\mathrm{E}$ and $\mathrm{U}$ would be linearly related. This approach has often resulted in optimum fishing effort being overestimated, probably because stocks are rarely at equilibrium. Secondly, parameters may be estimated by transforming the equations to linear form and fitting a linear regression (e.g. Waiters and Hilborn, 1976; Schnute, 1977) and, thirdly, time-series fitting may be used (Pella and Tomlinson, 1969). However, best fit procedures are unlikely to be reliable unless there is good contrast (i.e. a wide range of values for fishing effort) in the data (K. Patterson, personal communication, 1992).

Pella and Tomlinson's (1969) model has been applied to cephalopod stocks on the Saharan Bank (Sato and Hatanaka, 1983; Bravo de Laguna, 1989). Parameter values were estimated using an iterative procedure to minimise the difference between observed and expected yearly catches (Sato and Hatanaka, 1983). Resuits suggested that both octopus and cuttlefish stocks were overexploited, and the squid stock was apparently seriously depleted (Bravo de Laguna, 1989). Production models were also used in assessments of Sepia in the Arabian Sea (Sato and Hatanaka, 1983), in this case making the equilibrium assumption.

Application of biomass dynamic models to cephalopod stocks was strongly favoured by Anonymous (1988), who suggested that the relationships between quantities caught and stock biomass represent the best prospect for assessment, while recognising that biomass estimates are likely to be difficult. However, this class of models assumes that 
strong density dependent effects dominate population dynamics, implying a strongly depensatory stock-recruitment relationship whereas, in practice, recruitment to cephalopod stocks may depend on environmental conditions. Equilibrium models are, in any case, of doubtful value for such highly variable populations.

10. Cohort analysis and yield-per-recruit models

These methods-virtual population analysis (VPA), statistical catch-at-age methods and yield-per-recruit models-make use of catch-at-age data and assume the existence of discrete cohorts in the fished population. They depend on the existence of a straightforward method of ageing. In fish stock assessments, it is normal to derive age from established age-length relationships and, in any case, direct ageing from annual growth increments in otoliths is relatively straightforward.

For cephalopod species which live only 1 or 2 years, and which may be fished during only part of the year, data collection and analysis must operate on a shorter time-scale, e.g. daily or weekly. When population structure is very simple, with one or two distinct cohorts, the application of cohort analysis is straightforward. Indeed, if there is only one cohort, the model structure is reduced to no more than the underlying equation describing population dynamics.

The Illex argentinus fishery in the southwest Atlantic exploits a single annual cohort. Csirke (1987) used VPA to estimate the Illex stock using catch data from those countries involved in fishing (Beddington et al., 1990). For the Falkland Islands fishery, Rosenberg et al. (1990) made use of the standard catch equation for continuous fishing on a cohort (after Gulland, 1965) for assessing the stock. The catch at time $\mathrm{t}$ is given by $C_{t}=\frac{F_{t}}{F_{t}+M}\left\{1-e^{\left[-\left(F_{t}+M\right)\right]}\right\} N_{t}$

where $\mathrm{F}$, is instantaneous fishing mortality at $\mathrm{t}, \mathrm{M}$ is instantaneous natural mortality rate and $\mathrm{N}_{\mathrm{t}}$ is population size (number) at $\mathrm{t}$, which may be expressed as

$$
N_{t}=N_{0} \exp \left[-\left(\sum_{i=0}^{t-1} F_{i}\right)+M_{t}\right]
$$

where $\mathrm{N}_{\mathrm{o}}$ is initial recruitment. Assuming a linear relationship between CPUE and stock size $\left(F_{t}=q E_{t}\right.$, where $E_{t}$ is instantaneous fishing effort at time $\left.t\right)$, this gives a non-linear 
equation expressing the catch at time $t$ as a function of effort with parameters $q$ and $\mathrm{N}_{\mathrm{o}}$ (Rosenberg et al., 1990)

$$
C_{t}=N_{0} \exp \left[-\left(q \sum_{i=O}^{t-l} E_{i}\right)+M_{t}\right] \frac{q E_{t}}{q E_{t}+M}\left\{1-\exp \left[-\left(q E_{t}+M\right)\right]\right\}
$$

Rosenberg et al. solved the equation using non-linear regression for data from a single fishing season, i.e. as a depletion estimate of original stock size, an approach which is discussed more fully below (Section 12).

Yield-per-recruit models may be thought of as an extension of cohort analysis in which catch is expressed in terms of biomass rather than numbers by incorporating terms for growth and body weight. The basic models follow Beverton and Holt (1957) and Ricker (1958).

In the Northwest Atlantic squid fishery, two cohorts of Loligo pealei are normally identified each year and a modified Ricker (1958) yield-per-recruit model is used to provide monthly estimates of stock size and yield (Lange and Sissenwine, 1983). The equation is a direct derivation of Eq. (10), with additional terms added for instantaneous growth rate $\left(\mathrm{g}_{\mathrm{t}}\right)$, mean body weight at the start of the interval $\left(\mathrm{W}_{\mathrm{t}-1}\right)$, and spawning mortality $\left(\mathrm{S}_{\mathrm{t}}\right)$ added. Monthly yield $\left(\mathrm{Y}_{\mathrm{t}}\right)$ for each cohort is then given by

$$
Y_{t}=\frac{F_{t}}{F_{t}+M+S-g}\left\{1-e^{[-(F t+M t+S t-g t)]}\right\} N_{t} W_{t}
$$

For Illex illecebrosus in the Northwest Atlantic the equation used was again based on Eq. (10), but with two additional mortality terms, cannibalism mortality and migration mortality. Growth was assumed to fit a Von Bertalanffy curve (Lange and Sissenwine, 1983).

In some cephalopods, notably loliginid squid, growth rates are highly variable and length-age relationships consequently weak (Anonymous, 1993). The alternative approach of direct ageing is extremely time-consuming, since growth rings on statoliths are formed daily (Pauly, 1985; Jereb et al., 1991). In some groups, notably octopods, the statoliths lack clearly-defined growth rings. 
Where multiple cohorts are present and direct ageing is not attempted, additional procedures are needed to identify cohorts from length-frequency data before models are applied. Various computer software is available, including ELEFAN (Gayanilo et al., 1989).

'Cohorts' must be identified objectively rather than merely by visual inspection (Pauly, 1985). The Bhattacharya method for separation, as included in ELEFAN, assumes that population components have normal size distributions. Other packages assume different statistical distributions, e.g. log-normal. For both cohort analysis and yield-per-recruit analysis, it is necessary to be able to follow individual cohorts from month to month. This is done by fitting growth curves. Lines traced by eye, joining modes in successive months, cannot be regarded as proper growth-rate estimates (Pauly, 1985). Pauly advocates use of the Von Bertalanffy growth model with seasonal oscillations as a means of standardising growth estimates for different squid species, allowing comparative studies to be done. ELEFAN includes methods for estimating mortality and recruitment. Mortality may be estimated from length-converted catch curves. Lengths are converted to ages by application of the previously fitted set of growth parameters. Total mortality $(Z)$ is obtained from the descending right limb of a plot of log frequency against log age (the catch curve). It then remains to partition $\mathrm{Z}$ into natural $(\mathrm{M})$ and fishing (F) mortalities. One approach is to measure F directly. First, biomass (B) is estimated using the swept area method (Gulland, 1969). $\mathrm{F}$ is then derived from $\mathrm{F}=\mathrm{Y} / \mathrm{B}$, where $\mathrm{Y}$ is the catch in weight from the stock (Pauly, 1985). Pauly (1980) proposed the prediction of $\mathrm{M}$ from an empirical relationship with body weight, growth rate and sea water temperature developed for fish stocks:

$\log \mathrm{M}=-0.2107-0.0824 \log \mathrm{W} \infty+0.6757 \log \mathrm{K}+0.4627 \log \mathrm{T}$

where $\mathrm{K}$ is the annual growth rate, $\mathrm{W}$ is the weight in grams and $\mathrm{T}$ is the mean annual water temperature $\left({ }^{\circ} \mathrm{C}\right)$. An alternative equation utilises length instead of weight.

Cohort analysis and yield-per-recruit models have been applied in the fishery for giant squid Dosidicus gigas in the Gulf of California, where multiple microcohorts are present. These microcohorts were identified from analysis of monthly length-frequency data (Ehrhardt et al., 1983). 
While Pauly (1985) advocates the use of length-based cohort analysis for assessment of cephalopod stock, arguing that ageing using growth rings of statoliths involves too much work to be used routinely, there are reasons for viewing length based assessment procedures with scepticism. First, the validity of this approach depends on the existence of a stable age-length relationship and cephalopod growth rates are known to be highly variable. Growth in many cephalopod species probably does not fit a Von Bertalanffy growth model (Saville, 1987; Forsythe and Van Heukelem, 1987; Patterson, 1988) and apparent seasonal changes in growth rate may be an artefact of differential migration of larger members of a cohort (J.F. Caddy, personal communication, 1993). Patterson (1988) found that linear and Von Bertalanffy models fitted data on Loligo gahi equally well. Additionally, the reliability of statistical separation of complex length-frequency data into 'microcohorts' may be questioned, given the extended periods of spawning and recruitment observed in some cephalopods (Caddy, 1991). For migratory squid species, total mortality $(\mathrm{Z})$ cannot simply be partitioned into $\mathrm{F}$ and $\mathrm{M}$ : an additional term for emigration (E) must be included to avoid bias (Caddy, 1979).

\section{Depletion estimates of stock size}

This approach derives from Leslie and Davis (1939) and De Lury (1947) and assumes a closed population declining as a consequence of fishing mortality. The underlying population equations are similar to those used in cohort analysis. Both the Leslie and the De Lury estimates start from population dynamics and observation submodels and require data on catches, fishing effort, and an abundance estimate, e.g. catch per unit effort (CPUE). The population submodel for the De Lury makes more explicit assumptions about the distribution of fishing effort.

The submodels are combined to give an expression which can be treated as a linear regression model $(y=a+b x)$

$\mathrm{N}_{\mathrm{t}}=\mathrm{N}_{\mathrm{I}}-\mathrm{K}_{\mathrm{t}-1}$ or $\mathrm{N}_{\mathrm{t}}=\mathrm{N}_{\mathrm{I}} \mathrm{e}^{-\mathrm{qEt}}$

$\mathrm{y}_{\mathrm{t}}=\mathrm{qN}_{\mathrm{t}}$

$\mathrm{y}_{\mathrm{t}}=\mathrm{qN}_{1}-\mathrm{qK}_{\mathrm{t}-1}$ or $\log \left[\mathrm{y}_{\mathrm{t}}\right]=\log \left[\mathrm{qN}_{1}\right]-\mathrm{qE}_{\mathrm{t}}$

where $K_{t-1}$ is cumulative catch prior to time $t$, Et is cumulative fishing effort up to time $\mathrm{t}, \mathrm{Y}_{\mathrm{t}}$ is abundance index and $\mathrm{q}$ is the catchability coefficient. By regressing $\mathrm{y}$, on $\mathrm{K}_{\mathrm{t}-1}$ to 
obtain the best least-squares or maximum likelihood fit, the remaining parameters, including initial population size $\left(\mathrm{N}_{1}\right)$, may be estimated.

The fishery for Illex argentinus around the Falkland Islands is managed by application of methods based on modified Leslie-De Lury analysis (Rosenberg et al., 1990). CPUE is used as an abundance estimate, assuming that after CPUE reaches a peak it will subsequently decline in proportion to abundance and that catchability is consistent across the whole fleet. The population submodel is modified to include a term for natural mortality (Rosenberg et al., 1990). The final model, again solved as a linear regression, is

CPUE $E_{t}=q N_{0} e^{-(t+0.5) M}-q \sum_{i=0}^{t-1} C_{i} e^{-(t-i) M}$

where $\mathrm{M}$ is instantaneous natural mortality and $\mathrm{C}_{\mathrm{i}}$ is catch during interval $\mathrm{i}$.

Rosenberg et al. (1990) also derive a generalised model to allow the inclusion of several fleets with different catchability coefficients.

The De Lury method has also been applied in the giant squid fishery in the Gulf of California (Ehrhardt et al., 1983) and the Japanese fishery for Todarodes pacificus (Murata, 1989). More recently, an extended De Lury model was applied to assessment of Loligo pealei in the Northwest Atlantic (Anonymous, 1993; Brodziak and Rosenberg, 1993). The basic population equation is extended by adding a term quantifying migration through the area of interest.

13. General and empirical models

Given the general belief that growth rates in cephalopods vary widely in relation to environmental conditions, the observed wide range of size of adult body size at maturity within species, and the likely dependence of fecundity on body size (Coelho, 1985; Pauly, 1985; Marigold, 1987; Forsythe and Van Heukelem, 1987; Forsythe and Hanlon, 1989), it may be suggested that environmental conditions will prove to be important predictors of stock size. 
Ecosystem models, e.g. models relating catches to simple observable characteristics of water bodies (chlorophyll, temperature, nutrients, salts, etc.), have been useful tools for the management of fisheries in lakes, reservoirs and rivers. There are also a number of marine situations, e.g. individual bays or estuaries, short lengths of coastline, rias, etc. for which there might be the prospect of using such models (FAO, 1978).

Fogarty (1989) reviewed heuristic models for predicting yield or abundance of exploited marine invertebrates. These utilise empirically derived relationships and make no assumption about the underlying structure of the system. Typically for invertebrate fisheries, heuristic methods have involved examination of relationships between catch or abundance and environmental variables. Fogarty recommends the use of CPUE as an abundance estimate. Since recruitment is closely related to oceanographic parameters such as temperature, nutrient concentrations and primary production, introducing some of these variables into the models may explain some of the variance in annual recruitment (Cushing, 1975; Fogarty, 1989). Relationships between squid landings and temperature were found by Dow (1976) and Coelho and Rosenberg (1984).

Environmental variables may be included in time-series analyses. Box-Jenkins autoregressive integrated moving average (ARIMA) models explicitly incorporate the effects of 'memory' of past values (autoregression) and random shocks (moving averages). Underlying trends may be removed by 'differencing'. Environmental variables are added as 'transfer functions' and the impact of specific events may be modelled by 'intervention analysis' in time series analysis (Box and Jenkins, 1976). An overview of this procedure in the context of invertebrate fishery assessment is given by Fogarty (1989).

\section{Multispecies assessment}

The theories and models for stock assessment developed mainly between 1950 and 1970 were designed for single-species fisheries. Since then, world fisheries, have expanded both quantitatively and in the variety of species harvested. In many areas of the world, fisheries exploit several different species and it is not rare for twenty or more species to be caught in a single trawl haul. In such fisheries, cephalopods are usually a by-catch. This is the situation for the majority of the trawl fisheries in the ICES area. 
While single-species models, e.g. cohort analysis, are routinely applied to describe population dynamics of single species in mixed fisheries, they may be inadequate due to both biological and operational interactions. Thus, the stock levels of one exploited species may not be independent of the stock levels of other exploited species owing to predation or competition. This may be as true for single- species fisheries as it is for multispecies fisheries. Also, if fishing directed at one species catches other exploited species in appreciable amounts, management options for the target species may be constrained by management goals for the other species.

A variety of descriptive and quantitative models is now available for multispecies situations, including extensions of stock-recruitment models, virtual population analysis and production models as well as more general ecosystem models (Andersen and Ursin, 1977; Daan and Sissenwine, 1991). A common difficulty is that, however algebraically straightforward it may be to expand models to include more species, the increased number of parameters renders the derivation of independent and unbiased parameter estimates increasingly difficult (Hilborn and Waiters, 1992). Also, the data required and detailed ecological understanding necessary to apply multispecies are seldom, if ever, available.

The inclusion of cephalopods in a multispecies assessment alongside finfish stocks raises the further difficulty that one is not dealing with the same kinds of animals. This is more critical for some situations than for others. Thus, squid stocks could not realistically be included in a multispecies VPA with temperate fin fish because the timescales over which VPA is meaningful for squid and fish are quite different.

\subsection{Production models}

The simplest way of extending production models to multispecies situation is to consider the single-species equations as describing the changes in the total biomass of all species combined. Such aggregated production models avoid increasing the number of parameters and the approach has been applied to various groups of stocks. These overall Schaefer models generally seem to fit the data rather better than the fits obtained for their various component stocks (Pauly, 1979; Ralston and Polovina, 1982; Hilborn 
and Walters, 1992). From such models a Total Allowable Catch (TAC) for all the species involved in the fishery can be established rather than using an individual TAC for each species. Such an approach is likely to be useful only if fishing is completely unselective with respect to the component stocks and the stocks respond to fishing in the same way. Thus, including cephalopods and long-lived fish in the same model is unlikely to be realistic.

\section{Management}

Anonymous (1988) comment that most fisheries for cephalopods exploit more or less fully-grown animals and that growth overfishing should not be a problem. This is probably more true of jigging than trawl fisheries. Much fishing for cephalopods in fact takes place on pre-breeding stocks, as is the case in the Falkland Islands fishery for Illex argentinus (Rosenberg et al., 1990) and the UK fishery for Loligo forbesi (Pierce et al., 1994a). In the Falklands Illex fishery, the size of squid caught is essentially limited by the size of squid migrating through the Falkland Islands Interim Conservation and Management Zone (FICZ), since both early growth and spawning take place elsewhere. The UK by-catch fishery takes Loligo forbesi of a wide range of body sizes: mean mantle length at recruitment to the fishery is no more than half mean mantle length for fully mature animals (Pierce et al., 1994b). Thus growth overfishing may be a problem, arguably difficult to solve since squid are a by-catch.

For annual species, there is no buffer to the current season's fishing and failure of recruitment due to overfishing on the current year's stock can be catastrophic (Anonymous, 1988; Rosenberg et al., 1990). It follows that the management target for a fishery on annual cephalopods should be to allow sufficient spawners to escape the fishery so as not to reduce appreciably the probability of good recruitment in the following season (Beddington et al., 1990). If the stock-recruitment relationship is very weak it will be necessary to make more conservative estimates about the amount of fishing permitted.

Paradoxically, although recruitment over fishing may have more serious shortterm consequences for cephalopod stocks than for finfish stocks, in the slightly longer term, cephalopod stocks should be able to recover much more quickly (Caddy, 1983). Of 
course, since ecosystems may have multiple stable states, after over-exploitation any stock could move to a different, possibly lower, equilibrium population size (Hilborn and Waiters, 1992), e.g. because recruitment is insufficient to swamp predators (G. Tingley, personal communication, 1993).

Management options may be divided into short-term and long-term measures. Caddy (1983) argues that, in the absence of well-developed management mechanisms, emphasis should be given to long-term measures, i.e. decisions that do not require regular adjustment to offer significant benefits, e.g. mesh size regulations, fish size limits, pre-arranged seasonal or area closures, effort limitation by controlling the number or tonnage of boats. In contrast, there are various shortterm measures which require regular review and adjustment, e.g. granting additional temporary licences, quotas, variable timing of the start or end of the fishing season (Caddy, 1983; Hilborn and Waiters, 1992). Each has particular advantages and disadvantages; and there are of course invariably economic, social, legal or political constraints on management options, particularly for multispecies fisheries or fisheries in international waters. The highly mobile nature of cephalopods, particularly squid, means that a fished stock may pass only part of its lifecycle in waters controlled by a particular fishing nation.

Any management strategy carries the risk of being mistaken, resulting in over exploitation or under-exploitation; the former is clearly more critical for survival of the stock (Basson, 1993). For a general discussion of risk analysis in management of squid fisheries see Basson (1993).

Choice of gear is of particular relevance for management. Jigging is species selective and there is thus normally little or no by-catch of protected or otherwise unwanted species (Rathjen and Voss, 1987). A cephalopod stock may then be managed without the need to take account of operational interactions with other fisheries. However, a jigging fishery for squid may catch other squid species as a by-catch, e.g. Martiala hyadesi is caught as a by-catch of the Illex argentinus fishery in the southwest Atlantic (G. Tingley, personal communication, 1993).

Mesh size restrictions have been applied in the Saharan trawl fisheries for cephalopods, but primarily to reduce incidental capture of small sparids and hake; the effect on 
cephalopods is unclear (Caddy, 1983). Trawling experiments in the northwest Atlantic (Hurley and Mohn, 1979) in relation to the Illex illecebrosus fishery, suggest that the use of larger meshes, in addition to increasing the minimum size at capture, effectively postpones recruitment of small squid into the fishery and may increase yield per recruit.

Quotas are unlikely to be useful because of the high variability in stock sizes (Caddy, 1983; Beddington et al., 1990). Thus, if a quota is set at the start of the season, the difficulty of predicting recruitment may result in quotas that either risk overexploitation, damaging future recruitment (recruitment overfishing) or underexploitation owing to the need to allow for the occurrence of poor years (Caddy, 1983).

Rosenberg et al. (1990) and Augustyn et al. (1992) argue that the most effective means of managing squid fisheries is by regulating fishing effort. Certainly, a fixed effort will cause the catch to vary in proportion to stock size and reduces the risk of recruitment overfishing. However, for a large fishery with fixed effort, the resulting wide variation in annual catches may have adverse effects on the market $(\mathrm{G}$. Tingley, personal communication, 1993).

\subsection{The Falkland lslands Illex fishery}

This fishery is arguably the most closely and successfully regulated cephalopod fishery in the world. Illex argentinus show a fairly consistent annual migration in which maturing squid travelling southwards reach the Falkland Islands Interim Conservation and Management Zone (FICZ) in March and migrate out of the zone by July to spawn and die. The fishery, principally based on jigging, is thus largely concentrated in March to May. Catches steadily decline after peak CPUE is achieved (Fig. 1), allowing use of a modified De Lury depletion estimate of stock size.

The fishery was managed to achieve a constant (40\%) proportional escapement of spawning stock, i.e. constant harvest rate. Rosenberg et al. (1990) comment that the $40 \%$ escapement target is a conservative level intended to ensure stock conservation. This approach was probably unnecessarily conservative in years of high abundance and risks over-exploitation in years of very low abundance. 
Currently, the previous year's catchability coefficient estimates are used to estimate the amount of effort required to achieve $40 \%$ (proportional) escapement, hence the number of vessels to be licensed (post-season assessment). Real time (in-season) assessment is used to undertake real time management with the goal of constant spawner escapement. Population size can only be estimated when sufficient data have been collected from real time assessment. Harvest rates are monitored and in years of very high or very low abundance, a mid-season adjustment in effort can be made, either to allow increased fishing effort (at high stock levels) or to curtail fishing effort (at low stock levels), e.g. by closing the season early. Adjustments may also be made to compensate for changes in catching power (Beddington et al., 1990; Rosenberg et al., 1990; Basson et al., 1994).

The close regulation which operates is possible for two main reasons. First, the fishery is strictly licensed and vessels are required to provide data as a condition of obtaining a licence. There is also a good relationship between fishermen and authorities and little incentive to misreport catch and effort (Beddington et al., 1990). Secondly, the relatively predictable migration of Illex makes the assessments biologically feasible.

Recently, the same assessment procedures have been extended to the rest of the southwest Atlantic. There is considerable exploitation of the same stock in Argentinian waters and on the high seas prior to and following the Falklands fishing season. Three different models have been used, making differing assumptions about migrations and the relationship between stock-size and CPUE. While they produce similar predictions for recruitment, estimates of spawning stock biomass differ widely. Improvements in assessment will require a combination of improved data on catches in International waters and models which explicitly estimate migration (Basson et al., 1994).

There is a second major squid fishery in the FICZ, based on Loligo gahi. Annual catches are substantial (50 000-120 $000 \mathrm{t}$ annually), although smaller than catches of Illex argentinus. Similar assessment and management procedures are used for this species (G. Tingley, personal communication, 1993).

15.2. The Japanese Todarodes fishery 
The jig fishery on Todarodes pacificus is the largest cephalopod fishery in the world, but one which has declined in the last 20 years (Fig. 2). Murata (1989) attributes the decline to overfishing at a time when the stock had fallen naturally to a low level.

Japanese fishery policy has placed priority on efficient management of fishery operations rather than protection or effective utilization of fishery resources (Murata, 1989). In 1969 the Ministry of Agriculture, Forestry and Fisheries began introducing regulations, essentially to prevent disputes among fishery operators. The regulations involved licensing of larger fishing vessels, specified fishing grounds and close-seasons. A range of assessment procedures has been used including the Schaefer production model, stock-recruitment relationships, larval and pre-recruit surveys and De Lury analysis (Okutani, 1977; Murata, 1989). However, fishing effort has consistently exceeded the calculated optimum levels (Murata, 1989). Stocks in both the Pacific and the Sea of Japan fishing grounds declined during the 1970s, with some recovery in the 1980s.

\subsection{The UK fishery for Loligo forbesi}

In UK waters, Loligo forbesi is a by-catch of a multispecies fishery, primarily directed at whitefish, and represents a very small proportion of total fish landings. There is no management in UK waters, although a legal minimum size for squid landed is set in Portugal and parts of Spain (Guerra et al., 1994; Moreno et al., 1994). Both abundance and geographic distribution in UK waters appear to vary widely from year to year, in a manner which is currently unpredictable (Pierce et al., 1994a). Management options for squid are severely constrained by procedures used to regulate whitefish fisheries.

In EC waters, whitefish stocks are managed primarily by allocation of annual singlespecies quotas to each member nation; there are also restrictions on fishing gear (minimum mesh sizes) and, current in the UK, fishing effort. Since trawling is not species-specific, it is inevitable that fish will continue to be caught after the quota is exceeded, and (under current regulations) discarded. For Loligo forbesi, whether a target species or not, an annual quota would lead only to an increase of discarding; of squid if the squid quota was exceeded, or of fin fish if the squid quota remained to be filled. 
As a by-catch, it is possible that fishing mortality is a very small proportion of total mortality for Loligo forbesi. If so, many standard stock assessment models are completely inappropriate, although an erroneous assessment is also unlikely to be very damaging.

There are two reasons for supposing that management may become necessary: (a) if cephalopod abundance rises as finfish stocks decline, cephalopods may assume much greater importance; (b) the current level of demand for cephalopod products in the EC is met largely by imports so that increased directed fishing of cephalopods may be economically justified.

In either eventuality, assessment procedures would need to be in place to allow appropriate management decisions if and when they becomes necessary. For a mixed fishery in which cephalopods assume greater importance, optimum management for cephalopods may conflict with that for fin fish, e.g. because smaller mesh sizes may be desirable for cephalopods (Caddy, 1983).

The Scottish squid fishery has two components (Thomas, 1973; Pierce et al., 1994a): catches from coastal waters, e.g. the Moray Firth (Fig. 3) peak in October and November (Fig. 4). It is possible that depletion estimates could be used to estimate original stock size. It may be necessary to analyse data on a daily or weekly basis since the monthly summaries in official statistics are rather coarse for this purpose. The decline in landings and CPUE in the spring coincides with breeding (Pierce et al., 1994a) and may be driven largely by natural mortality. Consequently, since the stock estimate would become available only in the middle of the breeding season or later, it would be very difficult to ensure adequate escapement prior to breeding. In any case, most fishing effort is directed at whitefish and restriction of whitefish fishing to protect squid (which make up some $2 \%$ of all landings) is not currently a sensible option.

In some years there is also a summer fishery at Rockall (Fig. 3). Catches at Rockall decline very quickly, e.g. within 1 month, after reaching their peak (Fig. 5) and realtime assessment may thus be impossible. However, the fishery is at least to some extent directed and is prosecuted on pre-breeding animals and escapement could therefore be 
managed. Another uncertainty however is the relationship between Rockall and other stocks, and consequently the impact of regulating the Rockall stock is difficult to predict. While there is no evidence of genetic differences between squid caught at Rockall and Scottish coastal waters (Brierley et al., 1994; Pierce et al., 1994c) it is possible that there are two subpopulations with different breeding and migration patterns.

There have been various small-scale trials of jigging methods for loliginids in UK waters, most of which were unsuccessful. There were various reasons for failure however and it is by no means clear that appropriate jigs were used. Different types of jig are used in Japan to catch loliginids and ommastrephids and jigs used in most trials appear to have been of the latter type (see Pierce et al., 1994a). Also, jigging is used routinely to catch Loligo forbesi in the Azores archipelago, and is also used in artisanal loliginid fisheries in Spanish and Portuguese coastal waters (Guerra et al., 1992; Cunha and Moreno, 1994). Consequently, we suggest that a likely direction for expansion of cephalopod fishing in EC waters would involve development of jigging.

\section{Conclusion}

Juanico (1983) opines that "squids are not fish and.., few principles of fish biology apply to these molluscs". This is a testable hypothesis, and little is to be gained by inferring, from the existence of differences between fish and squid, that methods and models developed for fish populations will not work when applied to squid (Pauly, 1985). It may be is useful to apply models developed for fish to squid in order to evaluate and quantify the differences between squid and fish. This is not to imply that parameter values derived for fish should be used, although Pauly has also advocated doing just this to estimate mortality.

While some cephalopod resources may be more resistant to overfishing than Long-lived finfish, they remain susceptible to uncontrolled overfishing and some stocks have already declined (Bravo de Laguna, 1989; Caddy, 1989; Murata, 1989).

For cephalopods in mixed fisheries, Caddy (1983) has argued that management for cephalopods may be unnecessary because cephalopod stocks are likely to be more 
resilient to overfishing than are the finfish stocks. If anything, optimal management for cephalopods may thus harm finfish stocks and the development of specific gears is therefore desirable.

Assessment and management are both more important and more easily achieved in a directed fishery. The contrasting relative success of management for the two examples given above (Sections 15.1. and 15.2.) may be presumed to reflect the degree to which the results of assessment were translated into management action.

A number of requirements remain for the successful assessment and management for cephalopod fisheries (see Voss, 1973; Caddy, 1983; Anonymous, 1979, 1987, 1993; Guerra, 1992; Augustyn et al., 1992).

(a) The identification of cephalopod stocks; determination of their distribution, migrations, and factors affecting them. Voss (1973) observed that less than $10 \%$ of the world's oceans were being fished for cephalopods and, although some previously unexploited areas (e.g. the sub-Antarctic) are now fished, Guerra (1992) argues that there are still new cephalopod resources to be discovered.

(b) The collection of appropriate fishery statistical data by all countries involved in cephalopod fisheries, to provide high quality and long time-series data. on catches and fishing effort. Of EC countries, only the UK has detailed historical records of the amount and distribution of squid landings, and data on octopus landings have only recently been collected. Historical records of stock size are important for the understanding of both natural fluctuations and the effects of exploitation. Stockrecruitment relationships can be established only on the basis of very long time-series of data. Nations compiling fishery statistics should be encouraged to separate cephalopod data by species if possible. In some cases this may be particularly difficult, e.g. Loligo forbesi and L. vulgaris.

(c) Comprehensive knowledge of the species' life cycles, particularly with respect to the distribution of spawning sites and early life stages. 
(d) Development of recruitment estimates or indices by means of larval and pre-recruit surveys or establishment of stock-recruitment relationships. Since recruitment contributes almost the entire standing crop in any one year, knowledge of recruitment immediately provides an indicator of stock size.

(e) Development of methods for detecting and locating cephalopods, e.g. acoustic methods, and development of gear for capture of cephalopods, in particular gears which are specific to cephalopods, and studies of cephalopod behaviour in relation to fishing gear.

(f) Development of new, mathematically tractable models which bear a closer relationship with real life stocks.

(g) Studies of the role of cephalopods in exploited communities and ecosystems, particularly with respect to trophic interactions.

(h) Information on the physical and chemical parameters of the bodies of water in which the exploited communities live, also plankton productivity, especially in the vicinity of spawning grounds.

Acknowledgements

This work was supported by the Commission of the European Communities (Contracts MA. 1.146 and AIR I-CT92-0573). We thank N. Bailey, P.R. Boyle, J. Caddy, K. Patterson and G. Tingley for their constructive criticisms of the manuscript.

\section{References}

Ampola, V.G., 1974. Squid-its potential and status as a U.S. food resource. Mar. Fish. Rev., 36: 28-32.

Andersen, K.P. and Ursin, K., 1977. A multispecies extension to the Beverton and Holt theory of fishing with accounts of phosphorus circulation and primary production. Medr. Danm. Fisk.-og Havunders N.S., 7: 319-435. 
Anonymous, 1979. Report of the Working Group on Assessment of Cephalopods. ICES CM 1979/K: 3.

Anonymous, 1988. Report of the Study Group on Squid Assessment. ICES CM 1988/Assess: 1.

Anonymous, 1993. Report of the Study Group on Cephalopod Biology. ICES CM 1993/K: 66.

Arnaya, N., Sano, N. and Iida, K., 1988. Studies on acoustic target strength of squid I. intensity and energy target strengths. Bull. Fac. Fish. Hokkaido Univ., 39: 187-200.

Arnaya, N., Sano, N. and Iida, K., 1989. Studies on acoustic target strength of squid II. Effect of behaviour on averaged dorsal aspect target strength. Bull. Fac. Fish. Hokkaido Univ., 40: 83-99.

Arnold, G.P., 1979. Squid: a review of their biology and fisheries. Laboratory Leaflet No 48, Ministry of Agriculture, Fisheries and Food, Lowestoft, UK, 37 pp.

Augustyn, C.J., Lipinski, M.R. and Sauer, H.H., 1992. Can the Loligo squid fishery be managed effectively? A synthesis of research on Loligo vulgaris reynaudii. In:

A.I.L. Payne, K.H. Brink, K.H. Mann and R. Hilborn (Editors), Benguela Trophic Functioning. S. Afr. J. Mar. Sci., 12: 903-918.

Bas, C., 1979. Un modelo de distribución de dos especies: Pagellus acarnae y Octopus vulgaris influidos por la pesca y las condiciones ambientales. Inv. Pesq., 43: 141149.

Basson, M., 1993. Risk analysis in fisheries management: the Falkland Islands squid fishery as an example. ICES CM 1993/D: 70.

Basson, M., Beddington, J.R., Crombie, J.A., Holden, S.J., Purchase, L.V. and Tingley, G.A., 1994. Assessment and management techniques for migratory annual squid stocks: the lllex argentinus fishery in the Southwest Atlantic as an example. FAO, Rome, in press.

Beddington, J.R., Rosenberg, A.A., Crombie, J.A. and Kirkwood, G.P., 1990. Stock assessment and the provision of management advice for the short fin squid fishery in Falkland Islands waters. Fish. Res., 8: 351-365.

Beverton, R.J.H. and Holt, S.J., 1957. On the dynamics of exploited fish populations. Fish. Invest. Ser. 2, Vol. 19. Ministry of Agriculture and Fisheries, London. Boucaud-Camou, E. (Editor), 1991. The Cuttlefish. 1st Int. Symposium on the Cuttlefish Sepia. Caen, 1-3 June 1989. Centre de Publications de l'Université de Caen, France, 358 pp. 
Box, G.E.P. and Jenkins, G.M., 1976. Time Series Analysis: Forecasting and Control. Holden Day, San Francisco.

Boyle, P.R., 1990. Cephalopod biology in the fisheries context. Fish. Res., 8: 303-321. Bravo de Laguna, J., 1989. Managing an international multispecies fishery: the Saharan trawl fishery for cephalopods. In: J.F. Caddy (Editor), Marine Invertebrate Fisheries: Their Assessment and Management. John Wiley, New York, pp. 591-612. Brierley, A.S., Thorpe, J., Pierce, G.J. and Boyle, P.R., 1994. Genetic variation in Loligo forbesi in the Northeast Atlantic. Mar. Biol., in press.

Brodziak, J.K.T. and Rosenberg, A.A., 1993. A method to assess squid fisheries in the north-west Atlantic. ICES J. Mar. Sci., 50: 187-194.

Caddy, J.F., 1979. Preliminary analysis of mortality, immigration, and emigration of 1llex populations on the Scotian shelf. Working Pap. 79/11/13, ICNAF.

Caddy, J.F., 1981. Some factors relevant to management of cephalopod resources off West Africa. CECAF/TECH/81/37. CECAF Project, Dakar.

Caddy, J.F., 1983. The cephalopods: factors relevant to their population dynamics and to the assessment and management of stocks. In: J.F. Caddy (Editor), Advances in Assessment of World Cephalopod Resources. Fish. Tech. Pap. 231, FAO, Rome, pp. 416-449.

Caddy, J.F., 1989. A brief review of the distribution of world cephalopods and recent trends in fisheries as judged from FAO information sources. In: Squid 89 Lisbon: the 1st World Cephalopods Conference, 13-15 March 1989, Lisbon. Agra Europe, London, $256 \mathrm{pp}$.

Caddy, J.F., 1991. Daily growth rings on squid statoliths: an opportunity to test standard population models? In: P. Jereb, S. Ragonese and S. von Boletzky (Editors), Squid Age Determination using Statoliths. Proc. of the Int. Workshop, Instituto de la Pesca e del Pescato (I.T.P.P.-C.N.R.), Mazara del Vallo, Italy, 9-14 October 1989, Spec. Publ. No. 1, N.T.R.-I.T.P.P., Mazara del Vallo, pp. 53-66.

Carvalho, G.R. and Loney, K.H., 1989. Biochemical genetic studies on the Patagonian squid Loligo gahi d'Orbigny. I. Electrophoretic survey of genetic variability. J. Exp. Mar. Biol. Ecol., 126: 231-241.

Carvalho, G.R. and Pitcher, T.J., 1989. Biochemical genetic studies on the Patagonian squid Loligo gahi d'Orbigny. II. Population structure in Falkland waters using isozymes, morphometrics and life history data. J. Exp. Mar. Biol. Ecol., 126: 243258. 
Carvalho, G.R., Thompson, A. and Stoner, A.L., 1992. Genetic diversity and population differentiation of the shortfin squid lllex argentinus in the south-west Atlantic. J. Exp. Mar. Biol. Ecol., 158: 105-121.

Clarke, M.R., 1983. Cephalopod biomass-estimation from predation. Mere. Nat. Mus. Vic., 44: 95-107.

Clarke, M.R., 1987. Cephalopod biomass-estimation from predators. In: P.R. Boyle (Editor), Cephalopod Life Cycles, Vol. II. Comparative Reviews. Academic Press, London, pp. 221-237.

Coelho, M.L., 1985. Review of the influence of oceanographic factors on cephalopod distribution and life cycles. NAFO Sci. Counc. Stud., 9: 47-57.

Coelho, M.L. and Rosenberg, A.A., 1984. Causal analysis of some biological data for 1llex illecebrosus from the Scotian Shelf. NAFO Sci. Counc. Stud., 7: 61-66.

Csirke, J., 1987. The Patagonian fishery resources and the offshore fisheries in the Southwest Atlantic. Fish. Tech. Pap. 286, FAO, Rome, 75 pp.

Cunha, M.M. and Moreno, A., 1994. Recent trends in the Portuguese squid fishery. Fish. Res., 21: 231-241.

Cushing, D.H., 1975. Marine Ecology and Fisheries. Cambridge University Press, Cambridge.

Daan, N. and Sissenwine, M.P. (Editors), 1991. Multispecies models relevant to management of living resources, Proc. of a Symposium, The Hague, 2-4 October 1989. ICES Mar. Sci. Syrup. Vol. 193. ICES, Copenhagen, 358 pp.

De Lury, D.B., 1947. On the estimation of biological populations. Biometrics, 3: 145167.

Dow, R.L., 1976. Effects of climatic cycles on the relative abundance and availability of commercial marine and estuarine species. J. Cons., Cons. Int. Explor. Mer, 37: 274380.

Ehrhardt, N.M., Jacquemin, P.S., Garcia, F.B., González, G.D., López, J.M.B., Ortiz, J.C. and Solis, A.N., 1983. On the fishery and biology of the giant squid Dosidicus gigas in the Gulf of California, Mexico. In: J.F. Caddy (Editor), Advances in Assessment of World Cephalopod Resources. Fish. Tech. Pap. 231, FAO, Rome, pp. 306-340.

Evans, K., 1986. Arrow squid behaviour and vulnerability to netting techniques. Tech. Rep. 12, Department of Sea Fisheries, Tasmania. 
Fogarty, M.J., 1989. Forecasting yield and abundance in exploited invertebrates. In: J.F. Caddy (Editor), Marine Invertebrate Fisheries: Their Assessment and Management. John Wiley, New York, pp. 701-724.

Food and Agriculture Organization, 1978. Some scientific problems of multispecies fisheries. Fish. Tech. Pap. 181, FAO, Rome, 41 pp.

Food and Agriculture Organization, 1991. FAO Yearbook of Fisheries Statistics, Vol.

72. FAO, Rome, 653 pp.

Forsythe, J.W. and Hanlon, R.T., 1989. Growth of the eastern Atlantic squid, Loligo forbesi Steenstrup (Mollusca: Cephalopoda). Aquacult. Fish. Manage., 20: 15-33. Forsythe, J.W. and van Heukelem, W.F., 1987. Growth. In: P.R. Boyle (Editor), Cephalopod Life Cycles, Vol. II. Comparative Reviews. Academic Press, London, pp. 135-156.

Fry, E.E.J., 1949. Statistics of a Lake Trout Fishery. Biometrics, 5: 27-67.

Fox, W.W., 1970. An exponential surplus-yield model for optimizing exploited fish populations. Trans. Am. Fish. Sot., 99: 80-88.

Gaard, E., 1987. An investigation of the squid Loligo forbesi Steenstrup on Faroe Bank. ICES CM 1987/K: 18.

Gayanilo, F.C., Jr., Soriano, M. and Pauly, D., 1989. A draft guide to the complete ELEFAN software. ICLARM Contrib. No. 435, International Centre for Living Aquatic Resources Management, Manilla, Philippines.

González, A.F., Rasero, M. and Guerra, A., 1992. 1llex coindetii and Todaropsis eblanae (Cephalopoda, Ommastrephidae): their present status in Galician fisheries. ICES CM 1992/K: 5.

Guerra, A., 1985. La pesca de cefalópodos mediante poteras automáticas. Inf. Téc. Inv. Pesq., 123, 20 PP.

Guerra, A., 1992. Cephalopod resources of the world: A present day review. In: Proc. of the 2nd World Cephalopod Conference, 11-13 November 1991, Madrid, Agra Europe, London, pp. 1-14

Guerra, A. and Pérez-Gándaras, G.P., 1983. Recursos mundiales de cefalópodos: situación actual y perspectivas. Inf. Téc. Inst. Invest. Pesq., Vols. 102-104, 141 pp. Guerra, A., Rocha, F., Casas, F. and Fernández, M.T., 1992. Loligo vulgaris and Loligo forbesi (Cephalopoda: Loliginidae): their present status in Galician fisheries. ICES CM 1992/K: 40. 
Guerra, A., Sanchez, P. and Rocha, F., 1994. The Spanish fishery for Loligo: recent trends. Fish. Res., 21: 217-230.

Gulland, J.A., 1965. Manual of methods for fish stock assessment. FAO Fish. Tech. Pap. 40, Revision 1, FAO, Rome, 68 pp.

Gulland, J.A., 1969. Manual of methods for fish stock assessment. Part 1. Fish population analysis. FAO Manuals in Fisheries Science, No. 4, FAO, Rome, 154 pp.

Hamabe, M. and Shimizu, T., 1966. Ecological studies on the common squid Todarodes pacificus Steenstrup mainly in southwestern waters of the Sea of Japan. Bull. Jpn. Sea Fish. Res. Lab., 16: 13-55.

Hamabe, M., Hamuro, C. and Ogura, M., 1982. Squid Jigging from Small Boats. FAO Fishing Manuals, Fishing News Books, Farnham, UK, 74 pp.

Hernando, A.M. and Flores, E.C., 1981. The Philippine squid fishery: a review. Mar. Fish. Rev., 43: 13-20.

Hilborn, R. and Waiters, C.J., 1992. Quantitative Fish Stock Assessment: Choice, Dynamics and Uncertainty. Chapman and Hall, New York, 570 pp.

Howard, F.G., 1979. Recent trends in the Scottish fishery for Loligo forbesi, together with some notes on the biology of the species. ICES CM 1979/K: 36.

Howard, F.G., Ngoile, M.A. and Mason, J., 1987. Loligo forbesi: its present status in Scottish fisheries. ICES CM 1987/K: 5.

Hurley, G.V. and Dawe, E.C., 1980. Tagging studies on squid (Illex illecebrosus) in Newfoundland waters. NAFO SCR Doc. 80/II/33.

Hurley, G.V. and Mohn, R.K., 1979. Considerations on the management of the international squid (1llex) fishery in ICNAF subarea 4. Tech. Rep. Fish. Mar. Serv. Can. 883.

Jereb, P., Ragonese, S. and von Boletzky, S. (Editors), 1991. Squid age determination using statoliths. Proc. of the Int. Workshop, Instituto de la Pesca e del Pescato (I.T.P.P.-C.N.R.), Mazara del Vallo, Italy, 9-14 October 1989, Spec. Publ. No. 1, N.T.R.-I.T.P.P., Mazara del Vallo, 128 pp.

Jones, R., 1961. The assessment of long-term effects of changes in gear selectivity and fishing effort. Mar. Res. (Scotland), 1961 (2): 1-19.

Juanico, M., 1983. Squid maturity scales for population analysis. In: J.F. Caddy (Editor), Advances in Assessment of World Cephalopod Resources, Fish. Tech. Pap. 231, FAO, Rome, pp. 341-378. 
Kristensen, T.K., 1982. Multivariate statistical analysis of geographic variation in the squid Gonatus fabricii Lichtenstein 1818) (Mollusca: Cephalopoda). Malacologia, 22: $581-586$.

Lange, A.M.T. and Sissenwine, M.P., 1983. Squid resources of the Northwest Atlantic. In: J.F. Caddy (Editors), Advances in Assessment of World Cephalopod Resources. Fish. Tech. Pap. 231, FAO, Rome, pp. 21-54.

Leslie, P.H. and Davis, D.H.S., 1939. An attempt to determine the absolute numbers of rats on a given area. J. Anim. Ecol., 8: 94-113.

MacArthur, R.H. and Wilson, E.O., 1967. The Theory of Island Biogeography. Princeton University Press, NJ.

Mangold, K., 1987. Reproduction. In: P.R. Boyle (Editor), Cephalopod Life Cycles Vol. II. Comparative Reviews. Academic Press, London, pp. 157-200.

Martins, H.R., 1982. Biological studies on the exploited stock of Loligo forbesi (Mollusca: Cephalopoda) in the Azores. J. Mar. Biol. Assoc. UK, 62: 799-808.

Marlins, H.R. and Porteiro, F.M., 1988. The exploited stock of Loligo forbesi in the Azores: additional notes on biology and fisheries. ICES CM 1988/K: 8.

Mohn, R.K., 1981, Yield-per-recruit analysis of short-finned squid on the Scotian shelf by simulation. NAFO Sci. Counc. Stud., 3: 39-45.

Moreno, A., Cunha, M.M. and Pereira, J.M.F., 1994. Population biology of veined squid (Loligo forbesi) and European Squid (Loligo vulgaris) from the Portuguese coast. Fish. Res., 21: 71-86.

Murata, M., 1989. Population assessment, management and fishery forecasting for the Japanese cornmon squid, Todarodes pacificus. In: J.F. Caddy (Editor), Marine Invertebrate Fisheries: Their Assessment and Management. John Wiley, New York, pp. 613-636.

Murphy, G.I., 1965. A solution of the catch equation. J. Fish. Res. Board Can., 22: 191202.

Nesis, K.N., 1987. Cephalopods of the World. T.F.H. Publications, Neptune City, NJ.

Okutani, T., 1977. Stock assessment of cephalopod resources fished by Japan. Fish. Tech. Pap. No. 173, FAO, Rome.

Okutani, T., 1980. Useful and latent cuttlefish and squids of the world. Natl. Coop. Assoc. Squid Process. Japan, 66 pp. 
Okutani, T. and Watanabe, T., 1983. Stock assessment by larval surveys of the winter population of Todarodes pacificus Steenstrup (Cephalopoda: Ommastrephidae), with a review of early works. Biol. Oceanogr., 2: 433-456.

Osako, M. and Murata, M., 1983. Stock assessment of cephalopod resources in the Northwestern Pacific. In: J.F. Caddy (Editor), Advances in Assessment of World Cephalopod Resources. Fish. Tech. Pap. 231, FAO, Rome, pp. 55-144.

Patterson, K., 1988. Life history of Patagonian squid Loligo gahi and growth parameter estimates using least-squares fits to linear and von Bertalanffy models. Mar. Ecol. Prog. Ser., 47: 65-74.

Pauly, D., 1979. Theory and management of tropical multispecies stocks: a review with emphasis on the Southeast Asian demersal fisheries. ICLARM Studies and Reviews No. 1, ICLARM, Manila.

Pauly, D., 1980. On the interrelationships between natural mortality, growth, parameters and mean environmental temperature in 175 fish stocks. ICES J. Cons., 39: 175-192. Pauly, D., 1985. Population dynamics of short-lived species, with emphasis on squids. NAFO Sci. Counc. Stud., 9: 143-154.

Pella, J.J. and Tomlinson, P.K., 1969. A generalized stock production model. Bull. Int. Am. Trop. Tuna Comm., 13: 419-496.

Pierce, G.J., Boyle, P.R., Hastie, L.C. and Shanks, A.M., 1994a. Distribution and abundance of the fished population of Loligo forbesi in UK waters: analysis of fishery data. Fish. Res., 21: 193-216.

Pierce, G.J., Boyle, P.R., Hastie, L.C. and Key, L., 1994b. The life history of Loligo forbesi (Cephalopoda: Loliginidae) in Scottish waters. Fish. Res., 21: 17-41.

Pierce, G.J., Thorpe, R.S., Hastie, L.C., Brierley, A.S., Boyle, P.R., Guerra, A. and Jamieson, R., 1994c. Geographic variation in Loligo forbesi in the Northeast Atlantic. Mar. Biol., 119: 541-547.

Pope, J.G., 1972. An investigation of the accuracy of virtual population analysis using cohort analysis. Int. Comm. Northwest Atl. Fish. Res. Bull., 9: 65-74.

Ralston, S., 1976 and Polovina, J., 1982. A multispecies analysis of the commercial deep-sea handline fishery in Hawaii. Fish. Bull., 80: 435-448.

Rathjen, W.F., 1991. Cephalopod capture methods: an overview. Bull. Mar. Sci., 49: 494-505. 
Rathjen, W.F. and Voss, G.L., 1987. The cephalopod fisheries. In: P.R. Boyle (Editor), Cephalopod Life Cycles. Vol. II. Comparative Reviews. Academic Press, London, pp. 253-275.

Ricker, W.E., 1954. Stock and recruitment. J. Fish. Res. Board Can., 11: 559-623.

Ricker, W.E., 1958. Handbook of computations for biological statistics offish populations. Bull. Mar. Fish. Serv. Can. 119, 300 pp.

Rodhouse, P.G., 1989. Antarctic cephalopods-a living marine resource? Ambio, 18: 5659.

Roper, C.F.E., Sweeney, M.J. and Nauen, C.E., 1984. FAO Species Catalogue. Vol. 3. Cephalopods of the World. An Annotated and Illustrated Catalogue of Species of Interest to Fisheries. FAO Fish. Synopsis 125 (3), 277 pp.

Rosenberg, A.A., Kirkwood, G.P., Crombie, J.A. and Beddington, J.R., 1990. The assessment of stocks of annual squid species. Fish. Res., 8: 335-350.

Rowell, T.W., Young, J.H., Poulard, J.C. and Robin, J.P., 1985. Biological characteristics and biomass estimates of the squid (1llex illecebrosus) on the Scotian Shelf (Div, 4VWX) in 1984. NAFO SCR Doc. 85/27.

Sato, T. and Hatanaka, H., 1983. A review of assessment of Japanese distant-water fisheries for cephalopods. In: J.F. Caddy (Editor), Advances in Assessment of World Cephalopod Resources. Fish. Tech. Pap. 231, FAO, Rome, pp. 145-203.

Saville, A., 1987. Comparisons between cephalopods and fish of those aspects of the biology related to stock management. In: P.R. Boyle (Editor), Cephalopod Life Cycles. Vol. II. Comparative Reviews. Academic Press, London, pp. 277-290.

Schaefer, M.B., 1954. Some aspects of the dynamics of populations important to the management of commercial marine fisheries. Bull. Inter-Am. Trop. Tuna Comm., 1: 27-56.

Schnute, J., 1977. Improved estimates from the Schaefer production model: theoretical considerations. J. Fish. Res. Board Can., 34: 583-603.

Solis, M., 1991. Octopus fisheries in the Mexican water of the Gulf of Mexico and Caribbean Sea. Bull. Mar. Sci., 49 (1-2): 667. (Abstr.)

Sundet, J.H., 1985. A short review on the biology and fishery of the squid Todarodes sagittatus. ICES CM 1985/K: 44.

Thomas, H.J., 1969. Some observations on the exploitation and distribution of squid around Scotland. ICES CM 1969/K:29.

Thomas, H.J., 1973. Squid. Scott. Fish. Bull., 39: 35-39. 
Thomas, H.J. and Davidson, C., 1972. Further observations on the Scottish squid fishery. ICES CM 1972/K: 31.

Tomlinson, P.K., 1970. A generalization of the Murphy catch equation. J. Fish. Res. Board Can., 27: 821-825.

Voss, G.L., 1973. Cephalopod resources of the world. Fish. Circ. 149, FAO, Rome, 75 pp.

Voss, G.L., 1983. A review of cephalopod fisheries biology. Mem. Nat. Mus. Vic., 44: 229-241.

Waiters, C.J. and Hilborn, R., 1976. Adaptive control of fishing systems. J. Fish. Res. Board Can., 33: 145-159.

Worms, J., 1983. World fisheries for cephalopods: a synoptic overview. In: J.F. Caddy (Editor), Advances in Assessment of World Cephalopod Resources. Fish. Tech. Pap. 231, FAO, Rome, pp. 1-20.

Zuev, G.V. and Nesis, K.N., 1971. Squids (Biology and Fisheries). Pishchevaya Promyshlennost, Moscow, 360 pp. 
Table 1

Examples of cephalopod fisheries. For further details see Voss (1973), Arnold (1979),

Nesis (1987), Guerra and Pérez-Gándaras (1983), Roper et al. (1984) and Rathjen (1991)

\begin{tabular}{|c|c|c|c|}
\hline Area & $\begin{array}{l}\text { Main fished } \\
\text { species }\end{array}$ & Fishing methods & References \\
\hline UK & $\begin{array}{l}\text { Loligo forbesi } \\
\text { Sepia officinalis } \\
\text { Eledone cirrhosa }\end{array}$ & $\begin{array}{l}\text { Trawls, seines } \\
\text { (by-catch) }\end{array}$ & $\begin{array}{l}\text { Thomas (1969), Thomas and } \\
\text { Davidson (1972), Howard } \\
\text { (1979) } \\
\text { Howard et al. (1987), Pierce et } \\
\text { al. (1994a) }\end{array}$ \\
\hline $\begin{array}{l}\text { France, } \\
\text { Spain and }\end{array}$ & $\begin{array}{l}\text { Loligo forbesi } \\
\text { Loligo vulgaris }\end{array}$ & $\begin{array}{l}\text { Trawls (by- } \\
\text { catch), jigs; }\end{array}$ & $\begin{array}{l}\text { Boucaud-Camou (1991), } \\
\text { González et al. (1992), Guerra }\end{array}$ \\
\hline Portugal & $\begin{array}{l}\text { Todaropsis } \\
\text { eblanae } \\
\text { lllex coindetti } \\
\text { Octopus vulgaris } \\
\text { Sepia officinalis }\end{array}$ & $\begin{array}{l}\text { Various } \\
\text { traditional } \\
\text { methods for } \\
\text { octopus, e.g. } \\
\text { spears, traps, } \\
\text { cans }\end{array}$ & $\begin{array}{l}\text { et al. (1992), Guerra et al. } \\
\text { (1994), Guerra and Pérez- } \\
\text { Gándaras (1983), Moreno et al. } \\
\text { (1994), Cunha and Moreno } \\
\text { (1994) }\end{array}$ \\
\hline Norway & $\begin{array}{l}\text { Todarodes } \\
\text { sagittatus }\end{array}$ & Jigs & Sundet (1985) \\
\hline Faroes & Loligo forbesi & $\begin{array}{l}\text { Trawls (by- } \\
\text { catch) }\end{array}$ & Gaard (1987) \\
\hline $\begin{array}{l}\text { Azores } \\
\text { archipelago }\end{array}$ & Loligo forbesi & Jigs & $\begin{array}{l}\text { Martins (1982), Martins and } \\
\text { Porteiro (1988) }\end{array}$ \\
\hline $\begin{array}{l}\text { Saharan } \\
\text { Bank }\end{array}$ & $\begin{array}{l}\text { Octopus vulgaris } \\
\text { Loligo vularis } \\
\text { Sepia officinalis }\end{array}$ & Trawls & Bravo de Laguna (1989) \\
\hline $\begin{array}{l}\text { Northwest } \\
\text { Atlantic }\end{array}$ & 1llex illecebrosus & Trawls, jigs & $\begin{array}{l}\text { Lange and Sissenwine (1983), } \\
\text { Brodziak and Rosenberg } \\
\text { (1993) }\end{array}$ \\
\hline $\begin{array}{l}\text { Falkland } \\
\text { Islands }\end{array}$ & 11lex argentinus & Jigs, trawls & $\begin{array}{l}\text { Rosenberg et al. (1990), Basson } \\
\text { et al. (In Press) }\end{array}$ \\
\hline
\end{tabular}




\begin{tabular}{|c|c|c|c|}
\hline & Loligo gahi & & \\
\hline $\begin{array}{l}\text { Gulf of } \\
\text { California }\end{array}$ & Loligo opalescens & $\begin{array}{l}\text { Seine nets, lift } \\
\text { nets, roundhaul }\end{array}$ & $\begin{array}{l}\text { Ampola (1974), Ehrhardt et al. } \\
\text { (1983) }\end{array}$ \\
\hline & Dosidicus gigus & nets, pumping & \\
\hline $\begin{array}{l}\text { Gulf of } \\
\text { Mexico }\end{array}$ & Octopus maya & Trawl & Solis (1991) \\
\hline $\begin{array}{l}\text { Australia, } \\
\text { New }\end{array}$ & $\begin{array}{l}\text { Nototodarus } \\
\text { gouldi }\end{array}$ & Jigs, trawls & Evans (1986), Guerra (1992) \\
\hline Zealand & $\begin{array}{l}\text { Nototodarus sloani } \\
\text { Todarodes } \\
\text { filipovae }\end{array}$ & & \\
\hline Japan & $\begin{array}{l}\text { Todarodes } \\
\text { pacificus } \\
\text { Ommastrephes } \\
\text { bartrami } \\
\text { Symplectoteuthis } \\
\text { oualaniensis } \\
\text { Sepiella japonica } \\
\text { Sepia spp. } \\
\text { Loligo spp. } \\
\text { Sepioteuthis } \\
\text { lessonia } \\
\text { Dorytheuthis } \\
\text { bleekeri } \\
\text { Watasenia } \\
\text { scintillans } \\
\text { Onychoteuthis } \\
\text { borealojaponicus } \\
\text { Octopus spp. }\end{array}$ & $\begin{array}{l}\text { Jigs, trawls, } \\
\text { seines, pots, } \\
\text { spears, etc }\end{array}$ & $\begin{array}{l}\text { Okutani (1977), Hamabe et al. } \\
\text { (1982), Osako and Murata } \\
\text { (1983), Murata (1989) }\end{array}$ \\
\hline
\end{tabular}

Fig. 1. Trends in catches (millions of squid) and CPUE (thousands of squid per hour fishing) for the lllex argentinus fishery in the Falklands, 1987 (adapted from Rosenberg et al., 1990). Weeks are 7 day periods starting from 1.1.1987. 
Fig. 2. Annual changes in a stock size index (from jigging surveys in June) and CPUE (tonnes caught per fishing day by medium sized vessels) for Todarodes pacificus in the Sea of Japan, 1971-1984 (adapted from Murata, 1989).

Fig. 3. Map of the UK, showing the Moray Firth and Rockall areas.

Fig. 4. Total monthly landings (tonnes) and overall CPUE (tonnes per 1000 hours fishing) for squid caught in the Moray Firth by UK-registered vessels landing in Scotland, 1988 and 1989,

Fig. 5. Total monthly landings (tonnes) and overall CPUE (tonnes per 1000 hours fishing) for squid caught at Rockall by UK-registered vessels landing in Scotland, 1987. 